\title{
Analysis of beef meat quality in a slaughterhouse in Raska district
}

\author{
Milos Z. Petrovic ${ }^{*}$, Radojica Djokovic ${ }^{1}$, Dragan Vasilev ${ }^{2}$, Vesna Djordjevic ${ }^{3}$, Mirjana Dimitrijevic ${ }^{2}$, \\ Silvana Stajkovic ${ }^{2}$, Nedjeljko Karabasil ${ }^{2}$
}

A b s t $r$ a c t: The quality of slaughtered animals is a subject of interest, for both primary production and the meat industry. Classification of the carcasses is performed in slaughterhouses immediately after a veterinary examination and measurement of the carcasses weight. The present study examined the quality of young cattle carcasses in a slaughterhouse in the Raska district, according to the standard applied in the EU but not in Serbia. In total, 100 cattle carcasses (young bulls) were examined. For meat quality evaluation and grading, the following parameters according to the European standard for the classification of cattle carcasses SEUROP were used: slaughter weight, carcass weight and carcass yield, i.e. the carcass conformation, development of the muscles of the carcass as well as the development of basic parts (round, back and shoulder) and the degree of carcass fat tissue coverage.

Key words: beef meat quality, carcass classification, young bulls.

\section{Introduction}

The meat production process has several steps and each of them is significant for production of safe and quality product. Consumption of beef meat ranks in third place in Serbia, after pork and poultry (Ostojic et al., 2006). Improving carcass performance and meat quality traits are the main objectives of most research carried out in the beef production area. Meat quality is an important criterion that influences consumer decisions to purchase beef (Baltic and Boskovic, 2015; Djordjevic, 2016). Local demand is partially covered by imported beef because domestic production can not fulfill the requirements of the local market. In order to improve the current local situation, it is necessary to enhance and maintain agro-economic policies and strengthen the primary production. Some of the possible solutions for better production and quality are improving the qualities of breeding stock, nutrition and animal breeding technology (Aleksic et al., 2011; Sefer et al., 2015). Development of greater beef production volumes, improved beef meat quality and placement of higher-value meat on the market require improvement to the quality of meat from carcasses. Understandably, this refers to the edible parts of the carcass, carcass conformation and the carcass fat coverage, plus processing quality and sensory properties (Sretenovic et al., 2011; Ostojic-Andric et al., 2012).

The quality of the slaughtered animals is a subject of interest for both primary production and the meat industry. Based on the estimated value and classification of carcasses, it is possible to appropriately compensate producers i.e. the owners of animals, but also to assess the market value and industry profit. In order to assess carcass quality (meatiness) more thoroughly, parameters such as: slaughter weight, age of animal, carcass weight, carcass yield, carcass conformation, fat coverage, musculature length (m. longissimus dorsi) etc. should be considered. Animals are classified based on age, sex, physiological status and meatiness (Stamenkovic and Radovanovic, 2004). Carcass classification should be performed in slaughterhouses immediately after the veterinary examination and measurement of the carcasses weight.

In developed countries, quality is taken into account through a balanced approach of carcass meat quality assessment. The SEUROP classification system, used in the EU, enables prediction of the amount of meat in the carcass (EC No. 1249, 2008), which is the basis for determining the selling price of each animal. Given that monetary compensation

\footnotetext{
${ }^{1}$ University of Kragujevac, Faculty of Agronomy Cacak, Ljubicska 30, 32000 Cacak, Republic of Serbia;

${ }^{2}$ University of Belgrade, Faculty of Veterinary Medicine, Bulevar osobodjenja 18, 11000 Belgrade, Republic of Serbia;

3Institute of Meat Hygiene and Technology, Kacanskog 13, 11000 Belgrade, Republic of Serbia.
}

${ }^{*}$ Corresponding author: Petrovic Z. Milos, petrovic.milos87@kg.ac.rs. 
depends on the achieved quality, it is also an incentive for the improvement of cattle breeding, zootechnical conditions including hygiene, and welfare and health of animals in primary production. Slaughterhouses in which over 75 animals are slaughtered weekly (annual average) are obliged to apply the SEUROP classification system. The selection of personnel involved in this activity is of great importance and they require adequate education and training. The uniformity of the carcass quality assessment is achieved by precisely defined rules that include parameters and criteria in the corresponding regulations that concern: the category of carcass according to age and physiological status (calves, elderly calves, heifers, young bulls, castrated male animals and cows), carcass processing at slaughter for classification and categorization, criteria for scoring the carcass parameters of conformation and the fat tissue degree coverage. As already emphasized, carcass meat quality assessment has material significance since it enables payment for meat on the basis of quality achieved, and therefore, the SEUROP system has been further improved with subclasses within each class in order to determine the quantity of meat in the most complete manner.

The aim of the present study is to examine young bull carcass quality in a Serbian slaughterhouse according to slaughter weight, carcass yield, carcass conformation, and fat coverage degree, the criteria used in EU countries.

\section{Materials and methods}

The study was conducted from July 102014 to August 42014 in a slaughterhouse in Raska district, Serbia. The examination included carcasses of 100 slaughtered young bulls of the domestic Simmental breed, aged about one year from purchase.

Slaughter weight was measured after unloading at the slaughterhouse, while carcass weight was determined 45 minutes after slaughter, both on scales with accuracy of $\pm 0.5 \mathrm{~kg}$.

Carcass weight included the processed carcass without the following: internal organs (with the exception of the kidneys, which were included), skin, head, lower parts of legs (separated at the lower part of the carpal, tarsal joints were included), large blood vessels, spinal cord and the genital organs.

Carcass conformation and fat coverage were determined 45 minutes after slaughter, according to SEUROP classification (EC No. 1249, 2008). Based on the carcass conformation, carcasses were classified into six classes: S (superior): all profiles extremely convex; exceptional muscle development, double-muscled carcass type; E (excellent): all profiles convex to super-convex; exceptional muscle development; U (very good): profiles on the whole convex; very good muscle development; R (good): profiles on the whole straight; good muscle development; $\mathrm{O}$ (fair): profiles straight to concave; average muscle development; and $\mathrm{P}$ (poor): all profiles concave to very concave; poor muscle development.

Carcass fat coverage was estimated by numerical grades, from: 1 (low): none up to low fat cover; 2 (slight): slight fat cover, flesh visible almost everywhere; 3 (average): flesh, with the exception of the round and shoulder, almost everywhere covered with fat, slight deposits of fat in the thoracic cavity; 4 (high): flesh covered with fat, but on the round and shoulder still partly visible, some distinctive fat deposits in the thoracic cavity; to 5 (very high): entire carcass covered with fat; heavy fat deposits in the thoracic cavity.

Statistical analysis was performed using the statistical package Stats Soft INC (Statistica For Windows, version 6.0 computer program manual Tulsa, Stat Soft Inc., 1995). Descriptive statistical parameters (mean, standard deviation, standard error of the mean, minimum, maximum, and coefficient of variation) are presented in Table 1 .

\section{Results and discussion}

Table 1 shows the average mean slaughter weight, carcass weight and carcass yield of all 100 cattle carcasses.

Results from Table 1 show that average cattle slaughter weight was $518.77 \mathrm{~kg}$ with a coefficient of variation of $10.74 \%$. The mean carcass weight was $275.21 \mathrm{~kg}$ with a coefficient of variation of $10.4 \%$. The mean carcass yield was $52.61 \%$ and ranged from 48.00 to $63.00 \%$.

According to statistical data in Serbia, the average weight of adult animals before slaughter during 1995 to 2000 was $478 \mathrm{~kg}$ and from 2006 to 2011 was $504 \mathrm{~kg}$ (Dokmanovic et al., 2014). Lower weights compared to our results could be due to the fact that in those data, cattle were not separated by age and sex. Aleksic et al. (2002) showed the average animal weight before slaughter was $592.7 \mathrm{~kg}$, hot carcass weight with the lard was $329.9 \mathrm{~kg}$, while average carcass yield was $55.66 \%$. Similar results were found by Ostojic et al. (2007), who reported Simmental bulls weighed $579 \mathrm{~kg}$ after 477 days, while the average carcass yield was $57.1 \%$. In the same study, crossbreeds of Charolais and Limousine of younger age (446 and 443 days) achieved higher body weight at the end of fattening (621 kg and $590 \mathrm{~kg}$, respectively). 
Table 1. Average slaughter weight, carcass weight and carcass yield of young domestic Simmental bulls $(\mathrm{n}=100)$ in a slaughterhouse in Serbia

\section{Parameter}

Mean \pm standard deviation

Standard error

Minimum

Maximum

Coefficient of variation $(\%)$
Slaughter weight (kg) Carcass weight (kg)

$518.77 \pm 55.74$

5.6

376.0

652.0

10.74
$275.21 \pm 28.6$

210.0

342.0

10.4
Carcass yield (\%)
Drca (2009) reported that male domestic Simmental type cattle from three different producers in Serbia had carcass yields between $54.20 \%$ and $55.40 \%$. Similar results were reported by Lukic et al. (2016), who showed the average slaughter weight of male Simmental beef cattle was $586.9 \mathrm{~kg}$. The average carcass yield of male Simmental beef cattle was $56.56 \%$ (Lukic et al., 2016), which is higher than the Simmental carcass yield in our study (52.61\%). Among 54 young Simmental bull carcasses, the average weights of two groups of cattle were $478.40 \mathrm{~kg}$ and $569.42 \mathrm{~kg}$ (Petrovic et al., 2016). Average carcass yield was $51.87 \%$ (total for both groups), and ranged from 42.00 to $57.00 \%$ (Petrovic et al., 2016). Ciric et al. (2017) found mean slaughter weight of domestic Simmental bulls was $583.9 \mathrm{~kg}$, while average carcass yield was $56.32 \%$. Similar results were determined by Petrovic et al. (2017), who showed the average slaughter weight of male Simmental beef cattle was $516.23 \mathrm{~kg}$ with coefficient of variation of $10.47 \%$, while average carcass yield was $52.37 \%$ and ranged from 39.00 to $63.00 \%$. Finally, Petrovic et al. (2017) analyzed 80 young bull carcasses and found the

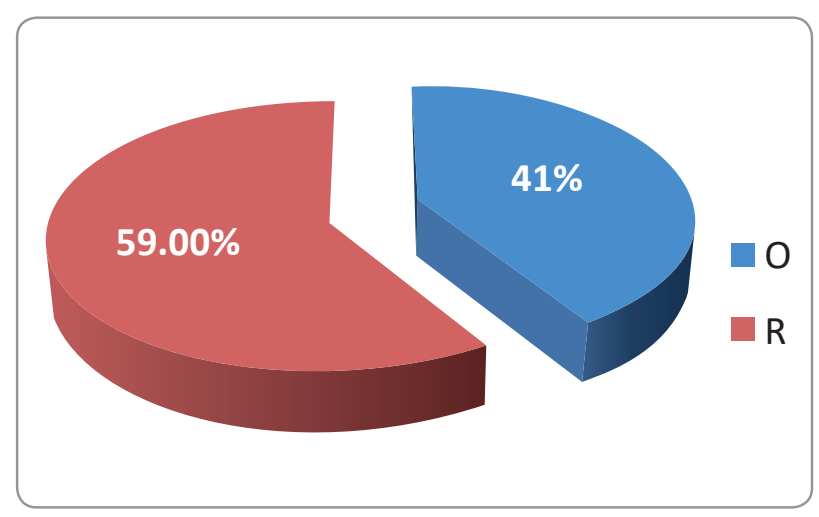

Figure 1. Percentage of carcass classes $\mathrm{O}$ and $\mathrm{R}$ among the studied cattle average live weight was $497.74 \mathrm{~kg}$ with a coefficient of variation of $5.83 \%$, while average carcass yield was $52.74 \%$, ranging from 42.00 to $59.00 \%$.

The following parameters are used for cattle carcass classification in the EU (EC No. 1249, 2008): carcass weight, conformation, meatiness, as well as the development of the prime cuts (round, the back and the shoulders), fat coverage degree, etc. A favorable conformation (excellent) of carcasses implies that all profiles are extremely well developed and convex. The round in excellent carcasses has a convex profile, the back is well developed and wide and the shoulders are filled and well-formed. Poor or unfavorable carcass conformation is characterized by concave, poorly developed leg, narrow back, straight shoulders and convex bones. Fat coverage refers to the amount and arrangement of subcutaneous, kidney and pelvic fat and residues on the inside surfaces of the chest and abdominal cavity. Fat protects the meat from oxidation, slows down the surface drying of meat, reduces the toughness and contributes to good juiciness and aroma (Vukovic, 2012). From a quality point of view, it is

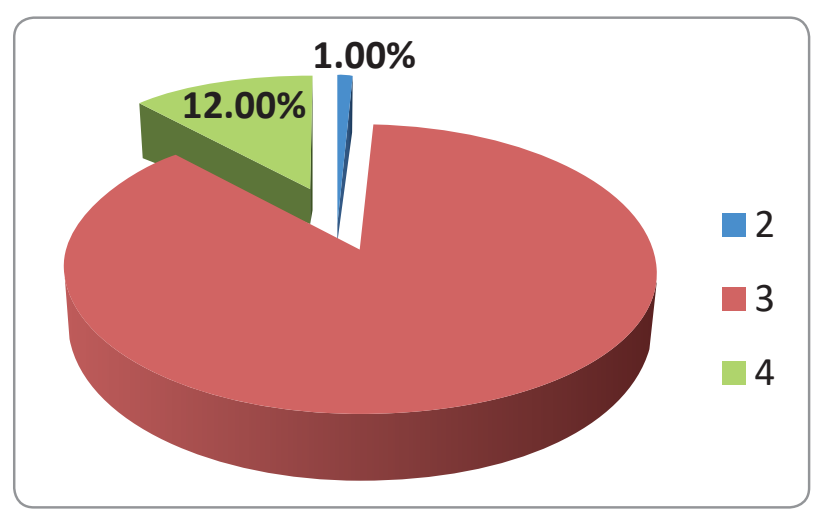

Figure 2. Percentage of studied cattle with degrees of carcass fat tissue coverage 
considered as favorable that a beef carcass has a uniform and well-distributed, continuous, but not too thick, layer of fat.

Figure 1 shows the results of carcass classification according to SEUROP classification, while Figure 2 shows the results of carcass classification according to fat coverage degree $(n=100)$. In terms of SEUROP classification, only two categories were observed among our studied cattle: $O$ (fair) $(n=41)$ and R (good) ( $\mathrm{n}=59)$. Regarding degree of fat coverage, three categories were determined (2, 3 and 4). One carcass was labeled as category 2 . More carcasses were labeled as category $3(n=71)$ than category $4(\mathrm{n}=12)$.

Similar results were obtained by Petrovic et al. (2016) who evaluated class of carcass based on the conformation as $\mathrm{O}$ for $77.5 \%$ of carcasses and as $\mathrm{R}$ for $22.5 \%$ of carcasses. The carcass fat tissue coverage degree was rated as 3 for $88.75 \%$ and 4 for $11.25 \%$ of carcasses (Petrovic et al., 2016). Petrovic et al. (2017) analyzed fat tissue coverage in 123 young bull carcasses. Their results showed three categories of fat cover $(2,3,4)$, similar to our current study. More $(n=107)$ carcasses were classified as category 3 than category 2 ( 1 carcass) or category 4 (15 carcasses) (Petrovic et al., 2017). In research by Petrovic et al. (2017) for all 80 young bull carcasses, only two categories, in terms of class were seen: $\mathrm{O}$ (fair) ( $\mathrm{n}=62,77.5 \%)$ and $\mathrm{R}$ (good) $(\mathrm{n}=18,22.5 \%)$.
Regarding fat tissue coverage, two categories were determined: 3 (mid coverage) and 4 (high coverage). More carcasses were labeled as category $3(n=71$, $88.7 \%$ ) compared to number of carcasses labeled as category $4(\mathrm{n}=9,11.2 \%)$.

Meat quality can be affected by pre-slaughter factors and post slaughter factors of animals including gender, age, feeding, animal handling, animal welfare, slaughter of animal, genotype of animals. In the EU, beef carcass classification for conformation and fatness plays an important role in international meat trade marketing. This is why meat price in the market depends on carcass conformation.

\section{Conclusion}

Based on the results and their critical considerations the following can be concluded:

- The mean carcass weight was $518.77 \pm 55.74 \mathrm{~kg}$;

- The mean carcass yield was $52.61 \pm 2.14 \%$ and it ranged from 48.00 to $63.00 \%$;

- Carcasses were evaluated as having conformation $\mathrm{O}$ in $41 \%$ of cases and as $\mathrm{R}$ in $59 \%$ of cases;

- The carcass fat tissue coverage degree was rated as 2 for $1 \%, 3$ for $12 \%$ and 4 for $87 \%$ of carcasses.

Acknowledgments: This research was supported by the Ministry of Education, Science and Technological Development of the Republic of Serbia, Projects No. TR 31034 and TR 31001.

Disclosure Statement: No potential conflict of interest was reported by the authors.

\section{References}

Aleksic, S., Petrovic, M. M., Pantelic, V., Novakovic, Z., Ostojic-Andric, D., Stanisic, N. \& Niksic, D. (2011). Chemical, technological and sensory properties of meat from different cattle genotypes. Biotechnology in Animal Husbandry, 27 (3), Book 2, 913-918.

Aleksic, S., Miscevic, B., Petrovic, M. M., Pavlovski, Z., Josipovic, S. \& Tomasevic, D. (2002). Investigation on factors affecting the results regarding the dressing percentage value of male young cattle of domestic Simmental breed and crossbreeds of domestic Simmental and Limousine breed (in Serbian). Biotechnology in Animal Husbandry, 18 (3-4), 1-14.

Baltic, Z. M. \& Boskovic, M. (2015). When man met meat: meat in human nutrition from ancient times till today. Procedia Food Science, 5, 6-9.

Ciric, J., Lukic, M., Radulovic, S., Janjic, J., Glamoclija, N., Markovic, R. \& Baltic, Z. M. (2017). The relationship between the carcass characteristics and meat composition of young Simmental beef cattle. IOP Conference Series: Earth and Environmental Science, 85, conference 1.

Dokmanovic, M., Lukic, M., Baltic, M. Z., Ivanovic, J., Markovic, R., Grbic, S. \& Glamoclija, N. (2014). Analysis of beef production volume in Serbia from 1985 to 2011. Tehnologija Mesa, 55 (1), 73-80.

Djordjevic, M. (2016). Comparative analysis of the lean meat of carcasses and selected quality parameters of meat of cattle in fattening. Doctoral dissertation. Faculty of Veterinary Medicine, University of Belgrade.

Drca, D. (2009). Examination of lean meat in beef cattle carcasses in slaughterhouse in Cajetina. University of Belgrade, Serbia.

Lukic, M., Ivanovic, J., Starcevic, M., Djordjevic, J., Markovic, R. \& Baltic, Z. M. (2016). Carcass performance of Simmental and Holstein Friesian beef cattle in Serbia Meat Technology, 57 (2), 95-101. 
Ostojic, D., Bogdanovic, V., Petrovic, M. M., Aleksic, S., Miscevic, B. \& Pantelic, V. (2006). Criteria of consumers when purchasing beef in retail stores, Part B: Position of beef compared to other meat types, reasons and frequency of its use in everyday nutrition and preparation methods. Biotechnology in Animal Husbandry, 22 (3-4), 45-53.

Ostojic-Andric, D., Aleksic, S., Hristov, S., Novakovic, Z., Petrovic, M. M., Niksic, D. \& Stanisic, N. (2012). Serbia in the implementation of SEUROP standard for beef carcass classification legislation, parameters and evaluation criteria. Biotechnology and Animal Husbandry, 28 (1), 47-58.

Ostojic-Andric, D., Bogdanovic, V., Aleksic, S., Petrovic, M. M., Miscevic, B., Pantelic, V. \& Josipovic, S. (2007). The effect of genotype on dressing percentage and tissue content of beef carcasses. Biotechnology in Animal Husbandry, 23 (3-4), 31-39.

Petrovic, M., Djokovic, R., Petrovic, D. M, Cincovic, M, Ilic, Z. Z, Cobanovic, N. \& Karabasil, N. (2017). Analysis of the degree covering of young bull carcass with fat tissue according to EU standard. $6^{\text {th }}$ International Symposium on Agricultural Sciences AgroReS 2017, Abstracts, Banja Luka, Bosnia and Herzegovina, 46.

Petrovic, M., Karabasil, N., Djokovic, R., Cincovic, M., Petrovic, D. M, Ilic Z. Z. \& Stanimirovic Z. (2016). Influence of the final mass of young bulls of the Simmental breed on dressing percentage. XXI Conference on Biotechnology, Faculty of Agronomy in Cacak, Proceedings, 21 (24), 577-580.
Petrovic, M., Djokovic, R., Cincovic, M., Ilic Z. Z, Petrovic, D. M, Cobanovic, N. \& Karabasil, N. (2017). Effect of age of young Simmental bulls on dressing percentage. Journal Acta Agriculturae Serbica, (XXII (43), 11-21.

Petrovic, M., Djokovic, R., Cincovic, M., Ilic, Z. Z, Petrovic, D. M, Doskovic, V. \& Karabasil, N. (2017). Analysis of the quality of carcasses of young Simmental bulls according to EU standard. Journal Acta Agriculturae Serbica (XXII) 44, 147-156.

Regulation (EC) No. 1249. 2008. Laying down detailed rules on the implementation of the Community scales for the classification of the beef, pig and sheep carcases and the reporting of prices thereof. Official Journal of the European Parliament.

Sretenovic, Lj., Pantelic, V., Novakovic, M., Novakovic, Z., \& Ostojic-Andric, D. (2011). Production of beef meat with functional food properties. Biotechnology in Animal Husbandry, 27 (3), Book 1, 373-385.

Stamenkovic, T. \& Radovanovic P. (2004). A contribution to study on carcasses of slaughtered cattle, pigs, sheep and fowls. Tehnologija Mesa, 45 (5-6), 219-224.

Vukovic, K. I. 2012. Basics of Meat Technology. Veterinary Chamber of Serbia, Belgrade.

Sefer, D., Markovic, R., Nedeljkovic-Trailovic, J., Petrujkic, B., Radulovic, S. \& Grdovic, S., 2015. The application of biotechnology in animal nutrition. Veterinarski Glasnik, 9 (1-2), 127-137. 